\title{
EGY VILLAMOSSÁGTANI PROBLÉMA, MATROIDELMÉLETI MEGOLDÁSSAL ÉS STATIKAI KÖVETKEZMÉNNYEL
}

\author{
PÉTERFALVI FERENC ÉS RECSKI ANDRÁS
}

Több mint fél évszázada vetődött fel a probléma, hogyan lehet eldönteni egy $n$-kapuról, hogy van-e hibrid leírása. A problémát Iri és Tomizawa matroidelméleti eszközökkel még a hetvenes években megoldotta, itt ennek egy természetes általánosítását vizsgáljuk. Megmutatjuk, hogy az általánosabb kérdéshez további - erősebb - matroidelméleti eszközök kellenek, végül megvizsgáljuk, hogy a rúdszerkezetek és a villamos hálózatok közötti régen ismert analógia ebben az esetben milyen statikai kérdéshez vezet.

\section{A villamosságtani probléma}

A villamos hálózatok alkatrészek összekapcsolásával jönnek létre. A legegyszerúbb alkatrész egy ellenállás (ilyennel lehet modellezni pl. egy izzót vagy egy vasalót); a két végpontja között mérhető $u$ feszültség és a rajta átfolyó $i$ áram közötti kapcsolatot az $u=R i$ egyenlet (az ún. Ohm-törvény) fejezi ki, ahol az $R$ konstanst az alkatrész ellenállásának nevezzük. Valamivel bonyolultabb, de még jól ismert alkatrész az ideális transzformátor; ha ennek az egyik oldali feszültségét és áramát $u_{1}$-gyel, illetve $i_{1}$-gyel, a másik oldalit pedig $u_{2}$-vel, illetve $i_{2}$-vel jelöljük, akkor a négy mennyiség közötti kapcsolatot két egyenlet fejezi ki: $u_{2}=k u_{1}$ és $i_{1}=-k i_{2}$, ahol a $k$ konstanst a transzformátor áttételének nevezzük. Ezek közös általánosításaként vezessük be az alábbi fogalmat:

1.1. Definíció. Lineáris (időinvariáns rezisztív) n-kapunak nevezünk egy olyan alkatrészt, amely $n$ póluspáron („kapun”) keresztül kapcsolódik a külvilághoz és amelyet az $\mathbf{A u}+\mathbf{B i}=\mathbf{0}$ egyenlet ír le, ahol $\mathbf{A}$ és $\mathbf{B} n \times n$-es valós elemü mátrixok, melyekre teljesül az $r(\mathbf{A} \mid \mathbf{B})=n$ feltétel, $\mathbf{u}$ és i pedig $n$ magasságú valós vektorok, melyek elemeit az egyes kapuk feszültségeinek, ill. áramainak fogjuk nevezni.

Így például az 1 . ábra első 1-kapuja az $u-R i=0$ egyenlettel leírt, korábban már látott ellenállás, a második és a harmadik a „rövidzár” és a „,szakadás”, melyek úgy írhatóak le, hogy $u=0$ (és $i$ tetszőleges), illetve $i=0$ (és $u$ tetszőleges). Az utolsó két (fiktív) alkatrész az $u=i=0$ egyenletrendszerrel leírt nullátor, illetve az „ $u$ is, $i$ is tetszőleges” tulajdonságú norátor, ezek a fenti definíció szerint nem 
tekinthetőek 1-kapunak, mert (A|B) rangja 2, ill. 0. Az 1.1. Definíció szerinti megadásuk rendre $(\mathbf{A} \mid \mathbf{B})=(1 \mid-R),(\mathbf{A} \mid \mathbf{B})=(1 \mid 0),(\mathbf{A} \mid \mathbf{B})=(0 \mid 1),(\mathbf{A} \mid \mathbf{B})=$ $\left(\begin{array}{c|c}1 & 0 \\ 0 & 1\end{array}\right)$, illetve az „üres mátrix” (hisz nincs egyenletünk).
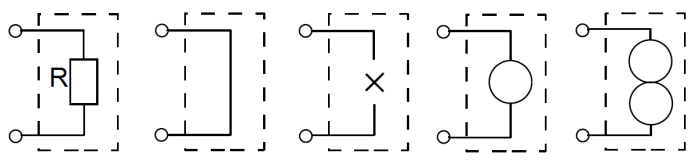

1. ábra: Ellenállás, rövidzár, szakadás, nullátor és norátor

Az $r(\mathbf{A} \mid \mathbf{B})=n$ rang-feltétel azt jelenti, hogy az $\mathbf{M}=(\mathbf{A} \mid \mathbf{B})$ mátrix oszlopai közül kiválaszthatunk $n$ darab lineárisan függetlent. Ha véletlenül az $\mathbf{A}$ oszlopai mind függetlenek, akkor az n-kapunak létezik az $\mathbf{u}=\mathbf{R} \mathbf{i}$ rezisztencia-leírása. Hasonlóképpen, ha a $\mathbf{B}$ oszlopai függetlenek, akkor létezik az $\mathbf{i}=\mathbf{G u}$ konduktancialeírás. A fenti példák közül a rövidzárnak csak rezisztencia-leírása, a szakadásnak csak konduktancia-leírása van, míg az ellenállásnak mind a kettő, ha $R \neq 0$.

1.1. Állítás. Helyezzünk az n-kapu minden kapujára áramforrást. A keletkezett villamos hálózat akkor és csak akkor lesz egyértelmüen megoldható (vagyis a keletkező feszültségek akkor és csak akkor lesznek egyértelmüen kifejezhetőek ezen áramok lineáris kombinációjaként), ha az n-kapunak létezik rezisztencia-leírása. Hasonlóképp ha minden kapura feszültségforrást helyezünk, akkor a konduktancialeírás létezése az egyértelmü megoldhatóság szükséges és elégséges feltétele.

1.2. Definíció. E két leírásmód közös általánosításaképp tegyük fel, hogy a kapuk $P=\{1,2, \ldots, n\}$ halmaza felbontható két diszjunkt $P=P^{\prime} \cup P^{\prime \prime}$ részhalmazra úgy, hogy az $\mathbf{A}$ mátrix $P^{\prime}$-nek megfelelő oszlopai és a $\mathbf{B}$ mátrix $P^{\prime \prime}$-nek megfelelö oszlopai együtt az $\mathbf{M}$ egy nemszinguláris $n \times n$-es részmátrixát alkossák. Legyen $\mathbf{u}^{\prime}$ és $\mathbf{u}^{\prime \prime}$ a $P^{\prime}$, ill. a $P^{\prime \prime}$ kapuk feszültségei által alkotott két vektor és legyen az $\mathbf{i}^{\prime}$ és az $\mathbf{i}^{\prime \prime}$ definíciója hasonló. Ekkor az $\mathbf{u}^{\prime}$ és $\mathbf{i}^{\prime \prime}$ vektorok egyértelmüen előállnak az $\mathbf{u}^{\prime \prime}$ és $\mathbf{i}^{\prime}$ függvényeként. Az ilyen $\mathbf{u}^{\prime}=\mathbf{U u}^{\prime \prime}+\mathbf{R} \mathbf{i}^{\prime}, \mathbf{i}^{\prime \prime}=\mathbf{G u}^{\prime \prime}+\mathbf{V i}^{\prime}$ előállítást az n-kapu hibrid leírásának nevezzük.

1.2. Állítás. Akkor és csak akkor létezik a kapuk halmazának olyan $P=P^{\prime} \cup P^{\prime \prime}$ partíciója, hogy a $P^{\prime \prime}$-kapukra feszültségforrást, a $P^{\prime}$-kapukra áramforrást helyezve egyértelmüen megoldható hálózatot kapunk (vagyis a $P^{\prime \prime}$-kapuk áramai és a $P^{\prime}$-kapuk feszültségei akkor és csak akkor lesznek egyértelmüen kifejezhetőek a többi mennyiség lineáris kombinációjaként), ha az n-kapunak létezik legalább egy hibrid leírása.

Ez az állítás különféle lineáris algebrai megfogalmazásokban számos helyen megtalálható az irodalomban [3, 5, 30, 32]. Például a 2. ábra első 2-kapujának 
létezik rezisztencia-leírása, nevezetesen $\left(\begin{array}{l}u_{1} \\ u_{2}\end{array}\right)=\left(\begin{array}{cc}R_{1}+R_{3} & R_{3} \\ R_{3} & R_{2}+R_{3}\end{array}\right)\left(\begin{array}{l}i_{1} \\ i_{2}\end{array}\right)$. Könnyü látni, hogy ha az $R_{1}+R_{3}, R_{2}+R_{3}, R_{1} R_{2}+R_{1} R_{3}+R_{2} R_{3}$ mennyiségek egyike sem 0 , akkor ennek a 2-kapunak létezik mind a négy hibrid leírása. A második 2-kapu egy feszültségvezérelt áramforrás, melynek konduktancia-leírása $\left(\begin{array}{l}i_{1} \\ i_{2}\end{array}\right)=\left(\begin{array}{ll}0 & 0 \\ g & 0\end{array}\right)\left(\begin{array}{l}u_{1} \\ u_{2}\end{array}\right)$, és ennek a 2-kapunak más hibrid leírása nem is létezik. A harmadik 2-kapu egy nullátor-norátor pár (amit nullor-nak is neveznek [3]), ennek semmilyen hibrid leírása nem létezik, azonban definíciónk szerint ez is 2-kapu az $(\mathbf{A} \mid \mathbf{B})=\left(\begin{array}{ll|ll}1 & 0 & 0 & 0 \\ 0 & 0 & 1 & 0\end{array}\right)$ leírással, jóllehet a nullátor és a norátor külön-külön nem tekinthetőek 1-kapunak. (Megjegyezzük, hogy a kapuk halmazának bármely rögzített $P=P^{\prime} \cup P^{\prime \prime}$ partíciója esetén nyilván található olyan $n$-kapu, melynek épp az a hibrid leírása nem létezik. Lehetséges az n-kapukat úgy parametrizálni, hogy kivétel nélkül mindegyiknek legyen leírása, de ez nem lineáris algebrai eszközökkel történik [29].)
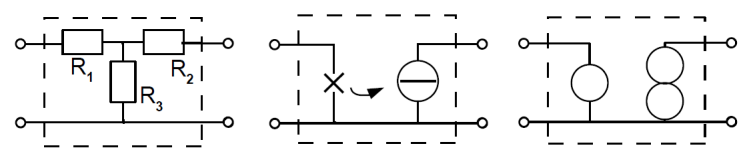

2. ábra: Egy rezisztív 2-kapu, egy feszültségvezérelt áramforrás és egy nullátor-norátor pár

A fentiek szerint a 3. ábra első hálózata, ahol a 2. ábrán már látott feszültségvezérelt áramforrás mindkét kapujára egy-egy feszültségforrást kapcsoltunk, egyértelműen megoldható, mert a 2-kapunak létezik konduktancia-leírása. Ha a feszültség- és áramforrások más variációját alkalmaznánk, nem jutnánk egyértelmủen megoldható hálózathoz. Azonban $g \neq 0$ esetén a 3. ábra második hálózata is egyértelmúen megoldható, ahol feszültség- vagy áramforrások helyett egy norátort és egy nullátort kapcsoltunk a kapukra. A 3. ábra két hálózatának közös általánosítása végett bevezetünk egy új fogalmat.
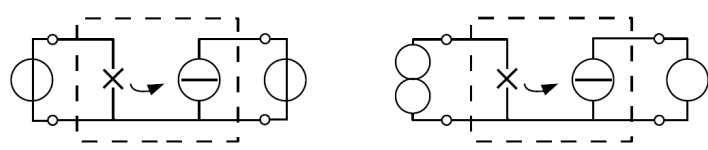

3. ábra: A feszültségvezérelt áramforrás két lehetséges beágyazása

1.3. Definíció. Egy $n$-kapu beágyazásának nevezzük a kapujain értelmezett $E: P \rightarrow\{$ feszülttségforrás, áramforrás, nullátor, norátor\} függvényt. Egy ilyen beágyazás szabályos, ha ugyanannyi kapuhoz rendelünk nullátort, mint norátort. 
Egy szabályos beágyazás megengedett, ha a keletkezett hálózat egyértelmủen megoldható. Ilyenkor a nullátoroknak és a norátoroknak ezt a közös számát a megengedett $E$ beágyazás szingularitási fokának nevezzük. Az összes megengedett beágyazás szingularitási fokainak halmazát az $n$-kapu spektrumának nevezzük.

1.1. KövetKeZMÉNY. Egy n-kapunak akkor és csak akkor van hibrid leírása, ha létezik 0 szingularitási fokú beágyazása, vagyis ha 0 eleme a spektrumának.

Az 1.2. Állítás általánosításához először a kapuk $P$ halmazának az 1.2. Definícióban leírt particionálását kell általánosítanunk. Legyen $P=$ $P_{U} \cup P_{I} \cup P_{U I} \cup P_{\infty}$ a kapuk felosztása olyan diszjunkt, nem feltétlenül nemüres részhalmazokra, ahol $P_{U I}$ és $P_{\infty}$ elemszáma azonos. Jelölje $\mathbf{u}^{(1)}$ a $P_{U} \cup P_{U I}$-beli kapuk feszültségeiből képzett vektort és $\mathbf{i}^{(2)}$ a $P_{I} \cup P_{U I}$-beli kapuk áramaiból képzett vektort. Legyen $\mathbf{u}^{(2)}$ és $\mathbf{i}^{(1)}$ a maradék feszültségek, ill. áramok vektora.

1.3. ÁlLíTÁs. Az alábbi három állítás ekvivalens minden n-kapura:

1. $A z \mathbf{u}^{(2)}$ és $\mathbf{i}^{(1)}$ vektorokat egyértelmüen meg lehet határozni az $\mathbf{u}^{(1)}$ és $\mathbf{i}^{(2)}$ ismeretében.

2. Az $M$ mátrix azon oszlopai, amelyek a $P_{U} \cup P_{\infty}$-beli kapuk áramainak és a $P_{I} \cup P_{\infty}$-beli kapuk feszültségeinek felelnek meg, egy nemszinguláris $n \times n$-es részmátrixot alkotnak.

3. Megengedett az a beágyazás, amely a $P_{U^{-}}$-kapukhoz feszültségforrást, a $P_{I^{-}}$ kapukhoz áramforrást, a $P_{U I}$-kapukhoz nullátort és a $P_{\infty}$-kapukhoz norátort rendel.

A 3. ábra szemlélteti, hogy a feszültségvezérelt áramforrás spektruma $\{0,1\}$. Könnyen ellenőrizhető, hogy a 2. ábra első 2-kapujának mindig van 0 szingularitási fokú beágyazása, 1 szingularitási fokú pedig akkor és csak akkor, ha $R_{3} \neq 0$. További példák az $\left(\begin{array}{ccc|ccc}1 & 0 & 0 & 0 & 0 & 0 \\ 0 & 1 & 0 & 1 & 0 & 0 \\ 0 & 0 & 0 & 0 & 1 & 0\end{array}\right)$ mátrixszal megadott 3-kapu, valamint az [5] cikkben szereplő 4-kapu, melynek mátrixa $\left(\begin{array}{cccc|cccc}1 & 0 & 0 & 0 & 0 & 0 & 0 & 0 \\ 0 & 0 & 0 & 0 & 1 & 0 & 0 & 0 \\ 0 & 0 & 0 & 0 & 0 & 0 & 1 & 1 \\ 0 & 0 & 1 & 1 & 0 & 0 & 0 & 0\end{array}\right)$. Az előbbinek a spektruma $\{1\}$; két megengedett beágyazása van, nevezetesen $E(3)$ mindenképp nullátor, de vagy $E(1)$ áramforrás és $E(2)$ norátor, vagy $E(1)$ norátor és $E(2)$ feszültségforrás. Az utóbbinak a spektruma $\{1,2\}$; négy megengedett beágyazása van, ugyanis $E(1)$ mindenképp norátor és $E(2)$ mindenképp nullátor lesz, de a 3. és a 4. kapura vagy egy feszültség- és egy áramforrást kell kötnünk 
(tetszőleges sorrendben), vagy egy nullátort és egy norátort (szintén tetszőleges sorrendben).

Nyilván minden $n$-kapu spektruma a $\{0,1, \ldots, m\}$ halmaz nemüres részhalmaza, ahol $m$-mel $n / 2$ alsó egészrészét jelöltük. Az $n$-kapu összes lehetséges beágyazásainak száma $4^{n}$, ezek közül a szabályosaké csak $\sum_{d=0}^{m}\left(\begin{array}{l}n \\ d\end{array}\right)\left(\begin{array}{c}n-d \\ d\end{array}\right) 2^{n-2 d}$. Mivel a szabályos beágyazások az $\mathbf{M}$ maximális $n \times n$-es részmátrixainak felelnek meg, adódik, hogy a szumma értéke $\left(\begin{array}{c}2 n \\ n\end{array}\right)$.

A nullátorok és norátorok fogalmát Carlin vezette be [3] és Oono [19] vetette fel, hogy mely $n$-kapuknak létezik legalább egy hibrid leírása. Természetesen egy adott $\mathbf{M}$ mátrix esetén ez elvben eldönthető mind a $2^{n}$ lehetséges partíció végigpróbálásával (minden esetben egy-egy $n \times n$-es részmátrix szingularitását kell vizsgálni), de - mint ezt a következő szakaszban látni fogjuk - létezik polinom idejü algoritmus is (Iri és Tomizawa, [11]). Ennek természetes általánosításaként kérdezhetjük, mi az egész spektrum meghatározásának a bonyolultsága.

\section{A matroidelméleti megoldás}

Iri és Tomizawa [11] fent említett eredményéhez matroidelméleti eszközökkel juthatunk el. Az $\mathbf{M}$ mátrix meghatároz egy $\mathcal{M}$ matroidot az oszlopvektorainak $S$ halmazán. Definiáljunk ugyanezen az $S$ halmazon egy másik $\mathcal{N}$ matroidot is, melyben egy részhalmaz akkor és csak akkor független, ha az $\left\{u_{1}, i_{1}\right\},\left\{u_{2}, i_{2}\right\}, \ldots,\left\{u_{n}, i_{n}\right\}$ párok mindegyikét legfeljebb egy elemben metszi. Vegyük észre, hogy ez épp egy partíciós matroid [22].

2.1. Állítás. (Iri és Tomizawa [11]) Az M által meghatározott n-kapunak akkor és csak akkor létezik hibrid leírása, ha ennek a két matroidnak létezik közös bázisa, ez pedig polinom idő alatt ellenőrizhető [6].

Jegyezzük meg, hogy mai szemmel ez az állítás teljesen kézenfekvő, de a hetvenes évek elején egyike volt annak a néhány eredménynek [11, 18, 22], amelyek felhívták a figyelmet a matroidok müszaki területeken való alkalmazhatóságára.

2.2. Állítás. [28] Általánosabban a mátrixával adott n-kapu spektruma polinom idő alatt meghatározható.

A bizonyítás három részből áll. Iri és Tomizawa eredményének kézenfekvő módosításával belátható, hogy ha a két fenti matroidnak nincs közös bázisa (amely esetben a matroid-metszet algoritmus egy maximális méretű közös független $X$ halmazt talál), akkor a spektrum legkisebb értéke $n-|X|$. Frank András egy javító utas algoritmussal [8] tetszőleges matroidokra bebizonyította, hogy ha a spektrum egynél több elemet tartalmaz, akkor mindig szomszédos egészek halmaza. Így csak 
a spektrum legnagyobb értékét kell meghatároznunk. Ez viszont nem más, mint annak a maximuma, hogy az $\left\{u_{1}, i_{1}\right\},\left\{u_{2}, i_{2}\right\}, \ldots,\left\{u_{n}, i_{n}\right\}$ párok közül hányat tartalmazhat egy $\mathcal{M}$-beli független halmaz. Ez a kérdés tetszőleges matroidok körében nem válaszolható meg polinom idő alatt, ld. [12, 16], de létezik hatékony algoritmus [15], ha az $\mathcal{M}$ reprezentálva van a valós test felett, márpedig esetünkben épp az $\mathbf{M}$ mátrix adja ezt a reprezentációt.

\section{A kapcsolódó statikai kérdés}

Egy $n$ pontú, $e$ élű egyszerű gráfot elképzelhetünk síkbeli rúdszerkezetként, melyben az élek merev rudaknak, a pontok gömbcsuklóknak felelnek meg. Intuíciónk alapján érezzük, hogy pl. a 3 hosszú körnek megfelelö rúdszerkezet merev lesz, a 4 hosszú körnek megfelelő szerkezet deformálható, de merevvé tehetjük egy átló hozzávételével.

A pontos definíció érdekében jelölje $\left(x_{i}, y_{i}\right)$ az $i$-edik csukló helykoordinátáit; ekkor a gráf $i$-edik és $j$-edik pontja közötti élnek megfelelö rúd azt jelenti, hogy az $\left(\left(x_{i}-x_{j}\right)^{2}+\left(y_{i}-y_{j}\right)^{2}\right)^{1 / 2}$ távolság állandó marad a rúdszerkezet mozgása során. Ezeknek az egyenleteknek a négyzetre emelésével, az idő szerinti deriválásával, majd 2-vel való osztásával nyerjük az $\left(x_{i}-x_{j}\right)\left(x_{i}^{\prime}-x_{j}^{\prime}\right)+\left(y_{i}-y_{j}\right)\left(y_{i}^{\prime}-y_{j}^{\prime}\right)=0$ egyenleteket. Ezeket együtt egy $\mathbf{W z}=\mathbf{0}$ egyenletrendszerként tekinthetjük, ahol $\mathbf{z}$ elemei az $x_{1}^{\prime}, x_{2}^{\prime}, \ldots, x_{n}^{\prime}, y_{1}^{\prime}, y_{2}^{\prime}, \ldots, y_{n}^{\prime}$ mennyiségek (a csuklók sebességkoordinátái) és az $e \times 2 n$ méretü $\mathbf{W}$ mátrixnak a sorai a gráf éleinek felelnek meg: a gráf $i$-edik és $j$-edik pontja közötti élnek megfelelő sor $i$-edik eleme $x_{i}-x_{j}, j$-edik eleme $x_{j}-x_{i},(n+i)$-edik eleme $y_{i}-y_{j},(n+j)$-edik eleme $y_{j}-y_{i}$, az összes többi eleme 0 lesz.

Ha az egész rúdszerkezet deformáció nélkül, merev testként mozog, akkor a csuklók sebességkoordinátái kielégítik ezt az egyenletrendszert. A síkban ezek a mozgások (eltolások, forgatások) a 2n-dimenziós térnek egy 3-dimenziós alterét alkotják. Így $r(\mathbf{W}) \leq 2 n-3$ mindig teljesül; akkor tekintünk merevnek egy rúdszerkezetet, ha $r(\mathbf{W})=2 n-3$.

Megjegyezzük, hogy a szakirodalomban (ld. pl. [10]) ezt a fogalmat infinitezimális merevségnek nevezik, más merevségi fogalmak is ismeretesek.

A korábban említett rúdszerkezet esetén, amelynek gráfja egy 4 hosszú kör volt, az egyenletrendszer mátrixa

$$
\left(\begin{array}{cccccccc}
x_{1}-x_{2} & x_{2}-x_{1} & 0 & 0 & y_{1}-y_{2} & y_{2}-y_{1} & 0 & 0 \\
0 & x_{2}-x_{3} & x_{3}-x_{2} & 0 & 0 & y_{2}-y_{3} & y_{3}-y_{2} & 0 \\
0 & 0 & x_{3}-x_{4} & x_{4}-x_{3} & 0 & 0 & y_{3}-y_{4} & y_{4}-y_{3} \\
x_{1}-x_{4} & 0 & 0 & x_{4}-x_{1} & y_{1}-y_{4} & 0 & 0 & y_{4}-y_{1}
\end{array}\right)
$$


Ennek rangja legfeljebb 4 (vagyis kisebb, mint $2 \cdot 4-3$ ), tehát a rúdszerkezet biztosan nem merev. A továbbiakban tekintsünk el az olyan „elfajuló” esetektől, amikor a 4 csukló közül valamelyik 3 „véletlenül” egy egyenesre esik (mert akkor a csukló-koordináták közötti algebrai kapcsolat csökkentené a rangot), így a mátrix rangja ténylegesen 4 lesz. Vizsgáljunk meg néhány példát, hogy mely oszlopnégyesek elhagyásával kapunk nemszinguláris mátrixot.

(a) Hagyjuk el az 1., 3., 5. és 7. oszlopokat - ez annak felel meg, hogy egyértelmüen meghatározható-e minden más sebességkoordináta, ha megadjuk az $x_{1}^{\prime}, x_{3}^{\prime}, y_{1}^{\prime}, y_{3}^{\prime}$ mennyiségek értékét. Legyen ez a négy érték 0 , ez fizikailag annak felel meg, hogy az 1 . és 3 . csuklót leszúrjuk, hisz sem $x$, sem $y$ irányban nem mozdulhatnak el. Ilyenkor a maradék két csukló sem mozdulhat el.

(b) Nem kapnánk viszont nemszinguláris mátrixot, ha az 1., 2., 5. és 6. oszlopokat hagynánk el, hisz a fentiekhez hasonlóan ez annak felelne meg, hogy az 1. és 2. (tehát két szomszédos) csuklót szúrunk le, ilyenkor viszont a másik két csukló még elmozdulhat.

(c) Nemszinguláris mátrixhoz jutnánk az 1., 2., 5. és 7. oszlopok elhagyásával. Ez fizikailag az 1. csukló leszúrásán kívïl azt jelenti, hogy a 2. csukló $x$ irányú és a 3. csukló y-irányú mozgását akadályoztuk meg - szemléletesen a 2. csukló csak egy függőleges, a 3. pedig csak egy vízszintes sínen mozoghat.

(d) Nemszinguláris mátrixhoz jutnánk az 1., 2., 3. és 8. oszlopok elhagyásával is - ez fizikailag az 1., 2. és 3. csukló függőleges, a 4. csukló vizszintes sínre helyezésének felel meg.

(e) Nem kapnánk viszont nemszinguláris mátrixot, ha az 1., 2., 3. és 4. oszlopokat hagynánk el - ez fizikailag annak felel meg, hogy akkor mindegyik csukló függőleges sínen mozoghatna.

A 4. ábra öt rajza szemlélteti a fenti lehetőségeket. Általában is megállapíthatjuk, hogy pontosan akkor jutunk nemszinguláris mátrixhoz, ha a rúdszerkezetet rögzítettük, vagyis az összes csukló mozgását megakadályoztuk.

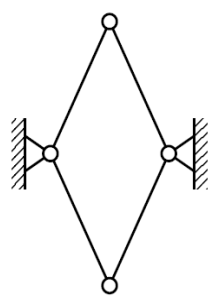

(a)

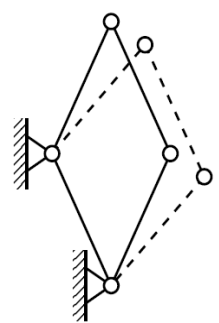

(b)

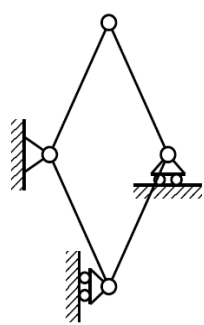

(c)

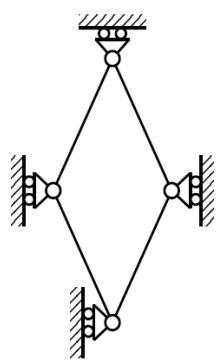

(d)

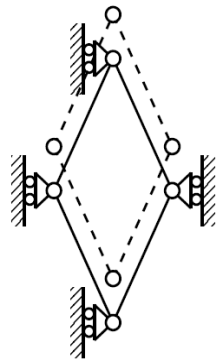

(e)

4. ábra 
Ha a fenti W mátrix egy villamos hálózat valamelyik 4-kapujának a leíró mátrixa lenne, akkor minek felelne meg ez az öt eset?

$\mathrm{Az}$ (a) és (b) esetekben 2-2 kapunak (az 1. és 3., ill. az 1. és 2. számúaknak) mind a feszültségét, mind az áramát előírnánk és azt kérdeznénk, hogy ezek egyértelmüen meghatározzák-e a maradék két kapu feszültségét és áramát - vagyis azt kérdeznénk, hogy egyértelmúen megoldható-e az a villamos hálózat, melynek az 1. és 3., ill. az 1. és 2. számú kapujaira nullátort, a maradék két kapura pedig norátort kötünk.

A (c) eset annak felel meg, hogy az 1. kapura nullátort, a 2.-ra feszültségforrást, a 3.-ra áramforrást, végül a 4 . kapura norátort kötünk.

A (d) és (e) eseteknek megfelelő hálózatokban viszont nem alkalmaztunk nullátor-norátor párt, hanem csak feszültségforrásokat (és a (d) esetben áramforrást is).

Ez a formális analógia a villamos hálózatok és a síkbeli rúdszerkezetek között (ahol tehát a nullátorok felelnek meg a csuklók leszúrásának, a feszültség- és áramforrások a csuklók sínre helyezésének, a norátorok pedig annak, hogy a csuklóval „nem csinálunk semmit”, vagyis a helyzetét csak a szomszédos csuklókhoz csatlakozó rudak határozzák meg), már mintegy 35 éve ismert, ld. [23-26].

Ennek megfelelöen definiálhatjuk a rúdszerkezet spektrumát is: egy $k$ szám akkor és csak akkor tartozzék bele ebbe a számhalmazba, ha van a rúdszerkezetnek olyan minimális rögzítése, ahol pontosan $k$ csuklót szúrtunk le. A minimális jelző arra utal, hogy a sínre helyezett csuklók $t$ számára teljesülnie kell, hogy $t+2 k=$ $2 n-r(\mathbf{W})$.

(Hangsúlyozzuk ki, hogy itt a (gráf által meghatározott) rúdszerkezet spektrumáról van szó - ne tévesszük össze a gráf spektrumával, ami teljesen más gráfelméleti fogalom [2].)

Hogyan határozható meg egy rúdszerkezet spektruma? A 3. szakaszban látottak alapján ez bármely numerikusan adott mátrix esetén polinom időben lehetséges: az intervallum legkisebb értékét a matroid partíciós algoritmussal, a legnagyobb értékét a jóval nehezebb lineáris matroid párosítási algoritmussal határozzuk meg és Frank András idézett tétele minden matroidra érvényes, nem csak az n-kapuk mátrixa által reprezentáltakra. Tekintettel azonban arra, hogy itt a mátrix nagyon szabályos szerkezetü, elképzelhető, hogy a feladat egyszerübb lesz.

Ahogy a korábbi példában (a 4 hosszú körnél) feltettük, hogy semelyik három csukló nem esik egy egyenesre, a továbbiakban általánosságban feltesszük, hogy a rúdszerkezet a gráfot a „lehető legszabálytalanabb módon” valósította meg, a csuklók „általános” helyzetüek, vagyis koordinátáik között semmilyen „véletlen” algebrai kapcsolat nincs. A merevség irodalmában ezt a gráf generikus megvalósításának nevezik, ez elérhető például, ha a koordináták algebrailag függetlenek a racionális test felett. Erre a feltevésre azért van szükség, mert ezáltal a merevség tényleg a gráf tulajdonsága lesz (nem pedig az adott gráf valamely konkrét megvalósításának a tulajdonsága, amely a gráf kombinatorikai tulajdonságain kívül a rudak hosszától is függne). 
Feltehetjük, hogy a rúdszerkezet gráfja összefüggő, hisz különben komponensenként vizsgálnánk a kérdést. Az is világos, hogy merev rúdszerkezetek spektruma mindig a $\{0,1\}$ halmaz lesz, ugyanis alapvetően kétféle minimális rögzítése lehet egy síkbeli merev rúdszerkezetnek: vagy leszúrunk egy csuklót és sínre teszünk egy másikat, vagy három csuklót teszünk sínre úgy, hogy a sínek között vízszintes is, függöleges is legyen.

Könnyen belátható, hogy a spektrum minimuma minden összefüggő gráf esetén 0 vagy 1, éspedig 1 a fákra és 0 a kört tartalmazó gráfokra. Az alapötlet az, hogy egy kör rögzítéséhez nincs szükség leszúrásra - gondoljunk a 4. ábra (d) rajzára -, a fákat viszont nem lehet csak sínekkel rögzíteni: a fent látott $t+2 k=2 n-r(\mathbf{W})$ egyenlet nem teljesülhet $k=0$ esetén, mert a mátrixnak csak $n-1$ sora van.

Így az egyetlen nyitott kérdés a spektrum maximumának a minél egyszerúbb (az általános eset matroidos apparátusát nem alkalmazó) meghatározása maradt. Ez egy nehezebb feladat, azonban, ahogy [21] észrevette, már megoldották [31], természetesen nem használva a spektrum itt bevezetett terminológiáját. A megoldás első lépése Fekete [7] eredménye, aki rúdszerkezetek olyan rögzítéseit vizsgálta, ahol kizárólag a csuklók leszúrását engedjük meg, sínre helyezésre nincs lehetőség. A rögzítéshez szükséges leszúrások minimális számának meghatározását visszavezette egy (nem feltétlenül páros) segédgráfban maximális élszámú párosítás keresésére. (A visszavezetés módja és helyességének egyszerü bizonyítása megtalálható [9]-ben is.)

Ennek az eredménynek az ismeretében azonnal adódik a kérdés, hogy az így kapott minimális leszúrás megfeleltethető-e a spektrum egy maximális elemének? Mivel minden minimális rögzítésre teljesül a $t+2 k=2 n-r(\mathbf{W})$ egyenlöség, vagyis a $t+2 k$ mennyiség egy rögzített érték, ezért $k$ akkor maximális, amikor $t+k$, vagyis a valamilyen módon rögzített csuklók együttes száma minimális. Ha egy minimális rögzítésben a sínre helyezett csuklókat is teljesen leszúrjuk, akkor a rúdszerkezet továbbra is rögzített marad, ezért $t+k$ nem lehet kisebb, mint egy minimális leszúrás elemszáma. Így csak az a kérdés, hogy ha adott egy minimális leszúrás, akkor ebből mindig megkaphatunk-e egy minimális rögzítést úgy, hogy néhány, a leszúrásban szereplő csukló rögzítését leszúrás helyett sínre cseréljük. Az igenlő válasz Streinu és Theran [31] eredményéből következik.

Ahhoz, hogy a kérdést pusztán kombinatorikai apparátussal vizsgálhassuk, először azt érdemes észrevenni, hogy nem fontos megkülönböztetnünk egymástól a vízszintes, illetve függóleges sínre helyezett csuklókat. Ehelyett beszélhetünk egyszerüen a sínre helyezett csuklók halmazáról, amelynek minden csuklóját egy tetszőleges irányú sínre helyezzük úgy, hogy az irányok együttesen generikusak legyenek. Az világos, hogy ha adott egy vízszintes és függőleges sínre helyezéseket tartalmazó rögzítés, akkor az ebben szereplő csuklók generikus sínre helyezése is rögzít. A fordított irány, hogy a generikusan sínre helyezett csuklókhoz hogyan tudunk hozzárendelni csak vízszintes és függőleges síneket úgy, hogy a rúdszerkezet rögzített maradjon, nem triviális, egy lehetséges megoldást mutat [31]. 
Mielőtt rátérnénk Streinu és Theran fő eredményére, érdemes bemutatnunk egy arra vonatkozó klasszikus tételt, hogy, rögzítésekről egyelöre nem beszélve, hogyan írhatjuk le kombinatorikai eszközökkel egy rúdszerkezet merevségét.

3.1. Definíció. Egy $G=(V, E)$ gráfot ritka gráfnak nevezünk, ha minden $X \subseteq V,|X| \geq 2$ ponthalmazra $i(X) \leq 2|X|-3$ teljesül, ahol $i(X)$ az $X$ által indukált élek halmaza.

3.1. ÁllítÁs. (LAMAN-TÉTEL). [13] Egy gráf egy generikus megvalósításához tartozó W merevségi mátrix sorai akkor és csak akkor függetlenek, ha a gráf ritka.

Streinu és Theran egy ezzel analóg tételt bizonyított ritka gráfok minimális rögzítéseiröl:

3.2. Definíció. Legyen $G=(V, E+L)$ egy olyan gráf, amely hurokéleket is tartalmazhat, és ahol $E$ jelöli a gráf „valódi”, $L$ a hurokéleinek halmazát. Azt mondjuk, hogy $G$ hurok-ritka, ha $(V, E)$ ritka és még az is teljesül, hogy minden $X \subseteq V$ ponthalmazra $i_{E+L}(X) \leq 2|X|$.

3.2. ÁlLíTÁs. [31] Legyen adott egy $G=(V, E)$ ritka gráf és ennek egy leszúrásokból és sínre helyezésekből álló rögzítése. Legyen a $G^{\prime}$ gráf a $G$ kibővítése hurokélekkel úgy, hogy minden olyan csúcshoz, amely egy leszúrt csuklónak felel meg, hozzáveszünk két hurokélet, és minden olyan csúcshoz hozzáveszünk egy hurokélet, amely sínre helyezett csuklónak felel meg. Ekkor $G$ rögzítése akkor és csak akkor minimális, ha $G^{\prime}$ hurok-ritka.

A minimális rögzítésekkel kapcsolatos algoritmusok alapja pedig a következő eredmény:

3.3. ÁLLíTÁs. [14] Egy rögzített $V$ csúcshalmazon megadható összes hurokritka gráf élhalmazai egy matroid független halmazait alkotják.

3.1. Megjegyzés. Az így kapott matroid bázisait pontosan azok a hurok-ritka gráfok alkotják, amelyeknél az $i_{E+L}(X) \leq 2|X|$ egyenlőtlenség $V$-re egyenlöséggel teljesül, vagyis az élszám a csúcsszám kétszerese. A hurok-ritkasághoz megkövetelt másik, $i_{E}(X) \leq 2|X|-3$ egyenlőtlenség $V$-n való egyenlőséggel teljesülése nem szükséges ahhoz, hogy egy gráf bázis legyen.

Mielőtt a fenti állításokat alkalmaznánk, még azt kell megjegyeznünk, hogy a rögzítések vizsgálatánál mindig feltehetjük, hogy a rögzítendő rúdszerkezetet leíró gráf ritka. Egy rögzítés ugyanis pontosan akkor rögzít egy gráfot, mint amikor annak egy maximális független részgráfját, maximális független részgráf keresésére pedig ismertek hatékony algoritmusok (pl. [1]). Ezzel pedig választ is kaptunk arra, hogy egy minimális leszúrásból kapható-e azonos számú csukló rögzítését tartalmazó minimális rögzítés: ha egy ritka gráf minden, egy minimális leszúrásában szereplő csúcsához hozzáveszünk két hurokélt, akkor egy olyan gráfot kapunk, 
amely az adott csúcshalmazon a hurok-ritkasági matroid szerint maximális rangú, így a matroid-tulajdonság miatt az eredeti ritka gráf élhalmaza ezen hurokélek egy részének hozzáadásával bázissá bővíthető, ami pedig egy minimális rögzítésnek felel meg.

A Fekete által adott algoritmus tehát elegendő arra, hogy meghatározzuk a spektrum maximális elemét, ha azonban egy konkrét minimális rögzítést is meg szeretnénk kapni, akkor nem elég tudnunk, hogy a minimális leszúráshoz tartozó, hurokélekkel kibővített gráf tartalmazza a hurok-ritkasági matroid egy bázisát, hanem meg is kell határoznunk egy ilyen bázist. Erre Lee, Streinu és Theran [14] algoritmusa használható. Végül, ha generikus sínre helyezések helyett egy kizárólag függőleges és vízszintes síneket tartalmazó rögzítést akarunk kapni, egy [31]-ben leírt algoritmus használható. Ennek az utolsó két lépésnek az elvégzésére egy alternatív eljárást ad [21].

Mivel már Fekete algoritmusa is feltételezi, hogy a gráf, amelyben minimális leszúrást keresünk, ritka, egy minimális rögzítést megtaláló algoritmus a következő három lépésből áll:

1. Megkeressük a kiindulási gráf egy maximális független élhalmazát.

2. A kapott ritka gráfhoz elkészítünk egy segédgráfot, és ebben maximális párosítást keresünk.

3. Az előző lépésben megkapott minimális leszúrás által meghatározott hurokélek felhasználásával a hurok-ritkasági matroid egy bázisává bővítjük a ritka gráfot.

$\mathrm{Az}$ 1. lépés futásideje az ismert legjobb algoritmusokkal $O\left(n^{2}\right)$, ahol $n$ a kiindulási gráf csúcsszáma. A 2. lépésbeli segédgráfnak $O(n)$ csúcsa és $O(n)$ éle van, így a Micali-Vazirani-algoritmussal [17] a lépés futásideje $O\left(n^{1,5}\right)$. A 3. lépés futásideje ismét $O\left(n^{2}\right)$, így azt kaptuk, hogy a spektrum maximális eleme meghatározható $O\left(n^{2}\right)$ futásidőben.

\section{Köszönetnyilvánítás}

A kutatást az NKFI (OTKA\#124171), valamint az EMMI BME Mesterséges Intelligencia FIKP (BME FIKP-MI/SC) programja támogatta.

\section{Hivatkozások}

[1] Berg, A. And Jordán, T.: Algorithms for graph rigidity and scene analysis, Proc. 11th Annual European Symposium on Algorithms (ESA) 2003, (G. Di Battista, U. Zwick, eds) Springer Lecture Notes in Computer Science, Vol. 2832, pp. 78-89 (2003). DOI: 10.1007/978-3-540-39658-1_10 
[2] Brouwer, A. E. And Haemers, W. H.: Spectra of graphs, Springer, New York (2012). DOI: $10.1007 / 978-1-4614-1939-6$

[3] Carlin, H. J.: Singular network elements, IEEE Trans. Circuit Theory, Vol. 11 No. 1, pp. 67-72 (1964). DOI: 10.1109/TCT.1964.1082264

[4] Chua, L. O. And Lam, Y. F.: A theory of algebraic n-ports, IEEE Trans. Circuit Theory, Vol. 20 No. 4, pp. 370-382 (1973). DOI: 10.1109/TCT.1973.1083715

[5] Chua, L. O. and Lam, Y. F.: Dimension of N-ports, IEEE Trans. Circuits and Systems, Vol. 21 No. 3, pp. 412-416 (1974). DOI: 10.1109/TCS.1974.1083876

[6] Edmonds, J.: Minimum partition of a matroid into independent subsets, J. Res. Nat. Bur. Stand. Vol. 69B Nos. 1 and 2, pp. 67-72 (1965). DOI: 10.6028/jres.069B.004

[7] Fekete, Zs.: Source location with rigidity and tree packing requirements, Operations Research Letters, Vol. 34 No. 6, pp. 607-612 (2006). DOI: 10.1016/j.orl.2005.10.005

[8] Frank, A.: személyes közlés, 2017. október.

[9] Frank, A. And Jordán, T.: Diszkrét optimalizálás, Typotex, Budapest (2014).

[10] Graver, J., Servatius, B. and Servatius, H.: Combinatorial rigidity, American Math. Soc. Graduate Studies in Mathematics, Vol. 2 (1993). DOI: 10.1090/gsm/002

[11] IRI, M. AND TomizawA, N.: A unifying approach to fundamental problems in network theory by means of matroids (in Japanese), Trans. Inst. Electron. \& Commun. Eng. Jpn. Vol. 57A, pp. 35-41 (1975).

[12] Jensen, P. M. And Konte, B.: Complexity of matroid property algorithms, SIAM J. Computing, Vol. 11 No. 1, pp. 184-190 (1982). DOI: 10.1137/0211014

[13] Laman, G.: On graphs and rigidity of plane skeletal structures, J. Eng. Math. Vol. 4, pp. 331-340, 1970. DOI: 10.1007/BF01534980

[14] Lee, A., Streinu, I. And Theran, L.: Graded sparse graphs and matroids, J. Univ. Comput. Sci., Vol. 13 No. 11, pp. 1671-1679 (2007). DOI: 10.3217/jucs-013-11-1671

[15] Lovász, L.: Matroid matching and some applications, J. Combinatorial Theory Ser. B, Vol. 28 No. 2, pp. 208-236 (1980). DOI: 10.1016/0095-8956(80)90066-0

[16] Lovász, L.: The matroid matching problem, Coll. Math. Soc. János Bolyai, Vol. 25, pp. $495-517$ (1981).

[17] Micali, S. And Vazirani, V. V.: An $O(\sqrt{V} E)$ algorithm for finding maximum matching in general graphs, IEEE 21st Annual Symposium on Foundations of Computer Science, pp. 17-27 (1980). DOI: 10.1109/SFCS.1980.12

[18] Narayanan, H.: Theory of matroids and network analysis, PhD thesis, Indian Institute of Technology, Bombay (1974).

[19] Oono, Y.: Formal realizability of linear networks, Proc. Symp. Active Networks and Feedback Systems, Polytechn. Inst. Brooklyn, pp. 475-485 (1960).

[20] Oxley, J.: Matroid theory, Oxford Univ. Press, Oxford (2006).

DOI: 10.1093/acprof:oso/9780198566946.001.0001 
[21] PÉterfalvi, F.: Sikbeli rúdszerkezetek spektrumának algoritmikus vizsgálata, BSc szakdolgozat, Budapesti Müszaki és Gazdaságtudományi Egyetem, Villamosmérnoki és Informatikai Kar, Budapest (2020).

[22] Recski, A.: On partitional matroids with applications, Coll. Math. Soc. János Bolyai, Vol. 10, pp. 1169-1179 (1973).

[23] ReCSKI, A.: A network theory approach to the rigidity of skeletal structures 1. Modelling and interconnection, Discrete Applied Mathematics, Vol. 7 No. 3, pp. 313-324 (1984). DOI: $10.1016 / 0166-218 X(84) 90007-6$

[24] Recski, A.: A network theory approach to the rigidity of skeletal structures 2. Laman's theorem and topological formulae, Discrete Applied Mathematics, Vol. 8 No. 1, pp. 63-68 (1984). DOI: 10.1016/0166-218X(84)90079-9

[25] Recski, A.: A network theory approach to the rigidity of skeletal structures 3. An electric model for planar frameworks, Structural Topology, Vol. 9, pp. 59-71 (1984).

[26] Recski, A.: Statics and electric network theory: a unifying role of matroids, W. Pulleyblank (ed): Progress in Combinatorial Optimization, Academic Press, London, pp. 307314 (1984). DOI: 10.1016/B978-0-12-566780-7.50024-6

[27] ReCski, A.: Matroid theory and its applications in electric network theory and in statics, Springer, Berlin (1989). DOI: 10.1007/978-3-662-22143-3

[28] ReCSKI, A.: Hybrid description and the spectrum of linear multiports, IEEE Trans. Circuits and Systems - II: Express Briefs, Vol. 66 No. 9, pp. 1502-1506 (2019). DOI: 10.1109/TCSII.2018.2890305

[29] Recski, A. And Zoller, V.: On the parametrization of linear memoryless 2-ports, Internat. J. Circuit Th. Appl. Vol. 10 No. 1, pp. 57-67 (1982). DOI: 10.1002/cta.4490100106

[30] SomedA, C.: The bigenerator - an active pathological network, IEEE Trans. Circuit Theory, Vol. 16 No. 1, pp. 125-126 (1969). DOI: 10.1109/TCT.1969.1082916

[31] Streinu, I. And Theran, L.: Slider-pinning rigidity: a Maxwell-Laman-type theorem, Discrete \& Computational Geometry, Vol. 44, pp. 812-837 (2010).

DOI: $10.1007 / \mathrm{s} 00454-010-9283-y$

[32] Willson, A. N.: New theorems on the equations of nonlinear DC transistor networks, Bell Syst. Tech. J., Vol. 49 No. 8, pp. 1713-1738 (1970).

DOI: $10.1002 /$ j.1538-7305.1970.tb04287.x

Péterfalvi Ferenc

Budapesti Müszaki és Gazdaságtudományi Egyetem, Villamosmérnöki és Informatikai Kar, Számítástudományi és Információelméleti Tanszék 1521 Budapest, Pf. 91.

fpeterfalvi@gmail.com 


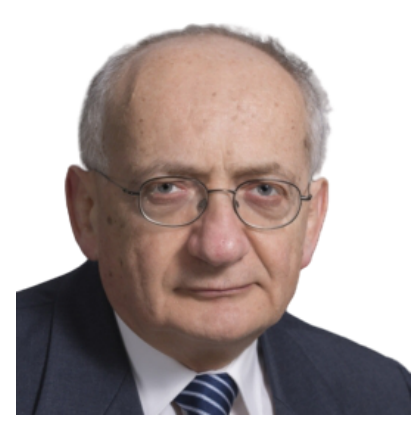

Recski András 1971-ben szerzett okleveles matematikusi diplomát az Eötvös Loránd Tudományegyetemen (ELTE), 1971-1984 között a Távközlési Kutatóintézet kutatója. 1972 óta oktat az ELTE-n, 1990 óta a Budapesti Müszaki Egyetemen (BME). 1988 óta egyetemi tanár, 1990-2011 között tanszékvezető a BME Számítástudományi és Információelméleti Tanszékén, majd 2012-2017 között a BME Matematika és Számítástudományi Doktori Iskola vezetője. 2009 óta az Aquincumi Technológiai Intézet tudományos igazgatója. Hosszabb ideig volt vendégprofesszor az USA-ban (Cornell University, Yale University), Kanadában, Németországban és Japánban. Kutatási területe: matroidelmélet, kombinatorikus optimalizálás és ezek müszaki alkalmazásai. 1969 óta a Bolyai János Matematikai Társulat tagja, 2006-2015 között a Társulat fótitkára. 1999-2005 között az MTA Matematikai Bizottságának alelnöke.

Recski András

Budapesti Müszaki és Gazdaságtudományi Egyetem, Villamosmérnöki és Informatikai Kar, Számítástudományi és Információelméleti Tanszék 1521 Budapest, Pf. 91.

recski@cs.bme.hu 
EGY VILLAMOSSÁGTANI PROBLÉMA, MATROIDELMÉLETI MEGOLDÁSSAL... 301

\section{A PROBLEM IN ELECTRIC NETWORK THEORY, ITS SOLUTION VIA MATROID THEORY AND A COROLLARY IN STATICS}

\section{FERenc PÉterfalvi And András Recski}

Oono asked more than 50 years ago, how one can determine if an $n$-port has a hybrid description. Iri and Tomizawa solved this problem in the early seventies, using tools of matroid theory. Here we study a natural generalization of this question. We show that stronger matroidal tools are required for the more general problem. Using the well-known analogy between frameworks and electric networks we also present the corresponding problem in statics. 